\title{
The Allocation time of Women to Livestock Business in Takalar Regency of South Sulawesi Province, Indonesia
}

\author{
Siti Nurlaelah, St. Rohani, Sitti Nurani Sirajuddin \\ Department of Social Economics, Faculty of Animal Science, Hasanuddin University, Makassar.90245. Indonesia
}

Received date: 19 April 2018, Accepted date: 15 June 2018, Online date: 29 June 2018

Address For Correspondence:

Siti Nurlaelah, Department of Social Economics, Faculty of Animal Science, Hasanuddin University, Makassar. 90245. Indonesia

Copyright $\odot 2018$ by authors and American-Eurasian Network for Scientific Information.

This work is licensed under the Creative Commons Attribution International License (CC BY).

http://creativecommons.org/licenses/by/4.0/

\section{(c) (i) Open Access}

\begin{abstract}
This research aimed to identifying and analyzing the role of women in improving the livestock business in Massamaturu Village, Polong Bangkeng Utara District, Takalar Regency, and South Sulawesi Province, Indonesia. The type of research used is quantitative descriptive in analyzing the data obtained through interviews and observations that began on March and completed by April 2018. The collected data from primary and secondary data. Analysis data was descriptive statistic. The result inferred that the domestic role played by female farmers spend a total of 5 hours per day. The productive role in livestock farming by a women takes around 3.83 hours per day. The total amount of domestic work time and productive of livestock women consumes a total time of 8.83 hours per day. This shows that the role of women is very important in improving the livestock business.
\end{abstract}

KEY WORDS

Role of Women, farm business, allocation, time, livestock

\section{INTRODUCTION}

The business activities of a productive livestock sub-sector involve the role of women in the implementation of the farm, especially the family farm. Efforts to involve the role of women in livestock farming are needed to improve the economy and efficiency regarding the utilization of local resources and to improve the status of women in sectorial activities. Rural women perform a reproductive role, encompassing childbearing, child rearing, and housework. At the same time, they also fulfill a productive role, engaging in paid labor activities outside the house and/or being in charge of a number of tasks related to household farming activities, including livestock management. In some developing countries, they makeupfor $43 \%$ of the agricultural labor force and contribute substantially to livestock management [1].

Women is a potential, which is now in the increasingly strong and tight global competition, then the program of women's empowerment becomes very important in responding to various challenges while utilizing opportunities in the future. The position of women who tend to be placed lower than men, causes women's ability to contribute and develop the potential is not optimal. Women's participation in development, should be accepted in recognition that women also have the right and ability to work outside the home. In general, women are driven to earn a living by the demands of the household economy, because the husband's income is not enough to meet the needs of the family [2]

Efforts to introduce new technology that does not take into account traditional practices by men and women will not be successful. Patterns in livestock activities (such as feeding, watering, and milking) shift in response to seasonal changes, and affect the labor input of women and men. As income-earning opportunities in areas of 
livestock production that are traditionally handled by women increase, control of these areas may be taken over by men. An agreement between men and women beneficiaries which protects the position of women must be found. The role of women and their empowerment in the local and regional livestock production system should receive special attention. The local practices at the base of livestock production must inform all development initiatives, and proposed technologies should be economically feasible, socially accepted and low risk [3, 4, 5]

The role of women in improving the household economy especially in the livestock sector in the Massammaturu village work every day, in addition to active work in households are also active in livestock. This is in accordance with the opinion of [6]. The role of women in the household at this time has shifted to the shutter outside the home, in the sense that women go out to work to help her husband. The phenomenon of women's role and contribution work is enormous, can be seen from the spirit of the women workers.

Efforts to involve women's gender in livestock farming activities are an effort to improve family economic security and efficiency of utilization of local resources and improve women's gender status in sectoral activities. The involvement of women in livestock farming activities is an effort to increase the power of input value contributed in the production process and decision making process. Women's participation in livestock farming activities is able to contribute financially in improving family income. As a member of the family, women's gender is also capable of controlling production assets. This situation is very different from the participation of women in subsistence agriculture where they act solely as laborers on land that is fully controlled by the head of the family. The purpose of this research is to find out the role of women in improving livestock business.

\section{RESEARCH METHOD}

The research was conducted between March to April 2018 at Massamaturu Village, Polong Bangkeng Utara Sub-district, Takalar Regencyt, and South Sulawesi Province, Indonesia. To know the role of women in increasing the household income, the study was conducted. The population consists of woman livestock farmers or who are not farmers of livestock. A total of 25 women were selected based on purposive sampling. The selection of Massamaturu village as the location of field practice is done considering the facts that this is one of the areas that have highly populated livestock and many breeders. The data analysis used in the research is quantitative descriptive. Quantitative descriptive research that involves a particular feature is used for this study which includes each type of research based on calculation percentage, average, squares, and other statistical calculations. The data was collected from the primary data. The primary data was obtained through interviews with the local community using a prepared list of questions. The questions included the identity of female breeders, condition of livestock owned by them and the outpouring of working hours in taking care of household as well as in taking care of livestock. Secondary data is the data obtained from the institutions in the form of general state of the region, population and other data related to the research

\section{Domestic Roles:}

\section{RESULTS AND DISCUSSION}

The domestic roles of women breeders in Massamaturu village, PolongBangkeng Utara Takalar District cover the activities such as house cleaning, taking care of children, cooking and washing. The other activities outside these activities are socializing with people around the home environment and the rest. Women, especially who have a husband, cannot be separated from his nature and as a housewife she must take care of her husband and the children. She need to meet the nutritional needs of family members and maintain their health. The amount of working time in domestic role played by the female breeders in Massamaturu Village, Polong Bangkeng Utara Takalar District is tabulated herewith (Table 1)

Table 1: Number of Working Time (Domestic) Women Breeders in Massamaturu Village, Polong Bangkeng Utara, Takalar District.

\begin{tabular}{|l|l|l|l|}
\hline No & Activity & Total Working Hours (25 People) & Average \\
\hline 1 & Cleaning the house & 32 & 1.28 \\
\hline 2 & Take care of child & 41,5 & 1.66 \\
\hline 3 & Cook & 22 & 0.88 \\
\hline 4 & Wash & 29,5 & 1.18 \\
\hline Sum & 125 & 5 & \\
\hline
\end{tabular}

Source: Primary Data that has been processed, 2017

Based on table 1, it can be observed that the total working time of female breeders in the Massamaturu Village is mostly spent in taking care of children with a total work time of 41.5 hours and an average of 1.66 hours per day. This gets affected by the number of children and their age with an average age below 7 years. While the least time is consumed by the female breeders during cooking a total work of 22 hours with an average of 0.88 hours per day. Cooking activities do not consume much time irrespective of the number of members in the family and in an average, a family has 4 people. Further the family is equipped with electronic devices for cooking. Cooking activities are usually done 2-3 times a day. This causes women to be less 
preoccupied with cooking, so that they can spend time to do other productive works. The average number of working hours per day for female breeders in doing all the domestic work is 5 hours per day.

The results of research conducted by [7] shows, of $53.44 \%$ of working women, $72.79 \%$ are permanent workers, meaning that women have certainty in obtaining income. [8] argue that the income of women workers in the clothing industry has a significant contribution to the increase in family income. The contribution of women can be regarded as a safety valve or a support for poor households to meet basic daily needs. [9] reported that the contribution of women in family income was $21.87 \%$, while the work performed jointly with husbands contributed $49.6 \%$. Furthermore, it is stated that the allocation of working time of transmigration women in oil palm companies is relatively the same as husbands that is 7 hours per day, while farming in the field itself is 4 hours 10 minutes per day

\section{Productive Role}

The role of women in the productive realm includes activities related to agriculture and livestock. In this case productive activities include activities of women in the breeding business that includes activities to take the feed, feed, and clean the cage. The number of working time of female breeders in the productive realm is illustrated in table 2 below:

Table 2: Number of Working Time per Day (Productive) Female Breeders in Massamaturu Village,

\begin{tabular}{|l|l|l|l|}
\hline No & Activity & Total hours/day(25 Org) & Average \\
\hline 1 & Taking feed & 33 & 1.32 \\
\hline 2 & Feeding & 44.5 & 1.78 \\
\hline 3 & Cleaning the cage & 18.2 & 0.73 \\
\hline Sum & 95.7 & 3.83 \\
\hline
\end{tabular}

Source: Primary Data that has been processed, 2017

Based on Table 2 it can be observed that the female breeders spend much of their daily time in taking the livestock for feeding. Women breeders do activities that take as much as 33 hours of food per week with an average of 1.32 hours per day. Since the location to feed the livestock is away from the home, it is observed as a time-consuming process. The activities of feeding includes the female breeder leaving home to take the livestock to feed, travel and trim and return home. While feeding activities, female breeders spend as much as 44.5 hours per week with an average of 1.78 hours per day.

The animals are fed three times a day i.e., morning, afternoon, and evening. The number of working hours of breeders, when observed in table 1, on the amount of working time of women, the time that women poultry rely on, depends on the number of livestock kept. The more the number of livestock kept, the longer the work is done, especially in the productive roles of women breeders. Furthermore, the activity of removing the cage, which in other words, disinfection of cage shows the total time taken for breeding work by the women breeders in cage-cleaning activities i.e., 18.2 hours per week with an average of 0.73 hours per day. The disinfection of the enclosure is performed before or after one cycle of maintenance process. Normally in this activity, many breeder women assist the family members.

The average outpouring of working time for woman breeders is obtained from this field practice and found to be 8.83 hours/day. This is derived from a combination of domestic working time and productive working time. In the rest of the time, the female breeders used to rest, relax and socialize with other residents. The magnitude of the outpouring of the working time for female breeders does not burden other family members and at the same time, it does not get a bad response too from their husbands.

This is in accordance with the opinion of [10] who stated that husbands of women who work in farms, feel helped when the farm activities are divided due to which their husbands too support the women in their work. In addition, their work as housewives can still be done properly. Furthermore, [11] added that the response of husbands to wives who work outside the home is considered as something reasonable for them. This is because, the work outside the home, is located not far from home, but just located in another yard from the house. So, the husband don't need to be afraid whether the wife left her domestic jobs.

\section{CONCLUSION:}

Based on the results of the research, the following conclusions are arrived at: The total domestic role of livestock farm women in Massamaturu Village, Polong Bangkeng Utara, Takalar District is performed for 5 hours per day and the total productive role played in the development of livestock at Massamaturu Village Polong Bangkeng Utara, Takalar District amounted to 3.83 hours per day

\section{REFERENCES}

[1] Amrawaty, A., S.N. Sirajuddin, V.S. Lestari, A. Abdullah, 2017. Gender Analysis on Beef cattle Farm. American-Eurasian Journal of Sustainable Agriculture, 11(6): 42-45. 
[2] Ratnawati, E., 2015. Motivasi Wanita Bekerjadalam Rangka Meningkat Perannya di Bidang Ekonomi. Jurnal. Fakultas Ekonomi dan Bisnis, Universitaswisnuwardhana. Malang.

[3] Vitayala, 2010. Peran Wanita, AkarBudaya, dan Analisis Peran: Era Transisi dan Propenasdalam Pemberdayaan Perempuandari Masa keMasa,Bogor: IPB Press.

[4] Sirajuddin, S., N. Asnawi, A. Rasyid, I. Mangalizu, A. Masnur, 2016. Competitiveness of Beef Cattle Fattening in Kulo Subdistrcit, Sidrap District, South Sulawesi. Advances in Environmental Biology, 10(1): 171-175.

[5] Sitti Nurani Sirajuddin, Siti Nurlaelah, Amidah Amrawaty, Amrullah T, St. Rohani, Ikrar Moh. Saleh, 2017. Relationship Between Farmers Characteristic and Income from Beef Cattle with The Traditional Profit-Sharing. American-Eurasian Journal of Sustainable Agriculture, 11(5): 29-34.

[6] Sujarwati, A., 2013. Peran Perempuandalam Perekonomian Rumah Tangga di Dusun Pantog Kulon, Banjaroya, Kalibawang, Kulon Progo. Skripsi. Program Studi Sosiologi, Fakultas Ilmu Sosial dan Humaniora, Universitas Islam Negeri Sunan Kalijaga. Yogyakarta.

[7] Mariun, N. Badrun, 2004. Kontribusi Perempuan Pada Peningkatan Pendapatan Rumah Tangga Miskin: Studi Kasus Di 4 Kabupaten/Kota. Warta Demografi Tahun 34 No. 3.

[8] Yuniarti, S., S. Haryanto, 2005. Pekerja Wanita pada Industri Rumah Tangga Sandang dan Kontribusinya Terhadappendapatan Rumahtangga di Kecamatan Sukun Malang. Jurnal Penelitian Universitas Merdeka Malang 17 (2).

[9] Hugeng, S., 2011. Alokasiwaktukerja dan kontribusiperempuanterhadappendapaankeluarga di permukimantransmigrasi Sei Rmbutan SP2. Jurnal Ketramsmigrasian, 28: 125-134.

[10] Mahdalia, A., 2012. Kontribusi Curahan Waktu Kerja Perempuan Terhadap Total Curahan Waktu Kerja Pada Usaha Peternakan Sapi Potong Di Pedesaan (StudiKasus, Kelompok Tani Ternak Lonrae Kelurahan Samaenre Kecamatan Sinjai Tengah Kabupaten Sinjai). Skripsi Fakultas Peternakan Universitas Hasanuddin Makassar.

[11] Haryanto, S., 2008. Peran Aktif Wanita Dalam Peningkatan Pendapatan Rumah Tangga Miskin: Studi Kasus Pada Wanita PemecahBatu di PuncakanakKecamatanTuguTrenggalek. JurnalEkonomi Pembangunan, 9(2). Program D3 Keuangan dan PerbankanUniversitas Merdeka Malang. 